\title{
Phytochemical Analysis and Antioxident Activity of Leptodermis Lanceolata Essential Oil from Pithoragarh, Uttarakand, India
}

\author{
Kavita Rawat ${ }^{1}$, Kundan Prasad ${ }^{1 *}$, Deepak Chandra ${ }^{1}$, Ganga Bisht ${ }^{1}$, I D Bhatt ${ }^{2}$, Anita Rana ${ }^{1}$ and Manoj Kumar \\ Devrani $^{1}$ \\ ${ }^{1}$ Department of Chemistry, DSB Campus, India \\ ${ }^{2}$ GB Pant National Institute of Himalayan Environment \& Sustainable Development, India
}

Submission: October 25, 2017; Published: November 08, 2017

*Corresponding author: : Kundan Prasad, Department of Chemistry, DSB Campus, KU Nainital, Uttrakhand Tel: 9690766978 ;

Email: gicgarkha@gmail.com

\begin{abstract}
Medicinal plants play a pivotal role in the health care of ancient and modern cultures. The plant Medicinal plants play a pivotal role in the health care of ancient and modern cultures. The plant Leptodermis lanceolata including leaves, stem flower, were extracted by hydro distillation method for 6 hours using Clevenger apparatus The hydro-distilled essential oil of Leptodermis lanceolata has been examined by means of gas chromatography-mass spectrometry (GC-MS). Take $1.0 \mathrm{ml}$ E. Oil of various code samples and mixed with in $4.0 \mathrm{ml}$ DMSO (Dimethyl sulfoxide). The prepared extract was used for the determination of antioxidant activity (i.e., DPPH assay \& ABTS assay) in among samples. The hydro-distilled essential oil of Leptodermis lanceolata has been examined by means of gas chromatography-mass spectrometry (GC-MS).Thirty-four constituents have been identified representing $72.29 \%$ of the total oil. The main compounds were phytol $19.44 \%$, Linalool $12.12 \%$, n-Hexadecanoic acid 7.55\%, 4(E)-4-Hexenyl acetate 4.49\%, the compound in minor amount were $\gamma$-Cadinene $0.21 \%$, Neryl acetone $0.32 \%$, 4,6- Dimethyl dodecane $0.32 \%$, The oxygenated diterpene (36.68\%), and oxygenated monoterpene (20\%), found in the oil as major components while sesquterpenes (5.72\%),were minor components. The results data obtained in the present study suggest that some essential oils possess strong medicinal activities, which can be utilized for treatment of certain diseases.
\end{abstract}

Keywords: Leptodermis lanceolata; $\gamma$-cadinene; Linalool; Essential oil; GC-MS Mass spectroscopy

Abbreviations: DMSO: Dimethylsulfoxide; DPPH 2: 2-diphenyl-1-picrylhydrazyl; GC-MS: Gas Chromatography/Mass Spectrometry; GC-FID: Gas Chromatography/Flame Ionization Detector; RI: Retention Index

\section{Introduction}

The many number of medicinal plants are used in the cellular and metabolic disease treatment such as diabetes, obesity and cancer etc. Ayurveda, the Indian system of medicine mainly uses plant based drugs or formulations to treat various human ailments because they contain the components of therapeutic value [1]. The genus Leptodermis Wall (Rubiaceae) is distributed in the northern hemisphere mainly confined to Himalaya, Japan and China [2]. The Rubiaceae are a family of flowering plants, the family contains about 13,500 species in 611 genera, which makes it the fourth-largest angiosperm family. Bark paste applied externally on forehead twice a day to treat migraine. Leaves browsed by livestock, stem used for fuel [3]. Several studies have shown that plant derived antioxidant neutraceuticals scavenge free radicals and modulate oxidative stress-related degenerative effects [4,5]. Medicinal plants have been used in traditional health care systems since prehistoric times and are still the most important health care source for the vast majority of the population around the world. Nature itself has a source of medicinal agents for thousands of years and an outstanding number of modern drugs have been isolated from natural sources, many based on their use in traditional system of medicines [6].

However, recent evidences from the pharmaceutical companies' shows that for some complex diseases, natural products still represent an extremely valuable source for the production of new chemical entities [7]. Some of the in vivo free radicals play a positive role in phagocytosis, energy production and regulation of cell growth etc. However, free radicals may 
also be damaging. Free radicals produced in the body react with various biological molecules namely lipids, proteins and deoxyribonucleic acids resulting in the imbalance between oxidants and antioxidants. Even though our body is safeguarded by natural antioxidant defense, there is always a demand for antioxidants from natural sources [8]. It is the first reported which is submitted in this journal.

\section{Materials and Methods}

\section{Plant Material}

The leaves of Leptodermis lanceolata were collected in the month of August 2016 from (Narayan nagar) Pithoragrah, location of Kumaun Himalayas, Uttarakhand. The plant was authenticated by Botanical Survey of India (BSI) Deharadune.

\section{Isolation of Essential Oil}

The plant Leptodermis lanceolata including leaves, stem were extracted by hydro distillation method for 6 hours using Clevenger apparatus. The oil was dried with anhydrous sodium Sulphate and stored at room temperature in a sealed vial until analysis was performed. The percentage oil yield was calculated based on the dry weight of the leaf. The oil yield was $(0.7 \%)$.

\section{GC-FID and GC-MS Analysis}

Essential oil analysis was performed by using GC-MS and GC-FID was performed on a Shimadzu QP-2010 instrument, equipped with FID, in the same conditions, except hydrogen was used as the carrier gas. The percentage composition of the oil samples were computed from the GC peak areas without using correction for response factors. The oils were analyzed using a Shimadzu GC/MS Model QP 2010 Plus, equipped with a Rtx5MS (30 m $\times 0.25 \mathrm{~mm} ; 0.25 \mathrm{~mm}$ film thickness) fused silica capillary column. Helium was used as carrier gas adjusted to $1.21 \mathrm{ml} / \mathrm{min}$ at $69.0 \mathrm{KPa}$; split less injection of $1 \mathrm{~mL}$, of a hexane solution; injector and interface temperature were $270 \mathrm{0C}$; oven temperature programmed was $50-2800 \mathrm{C}$ at $3 \mathrm{C} / \mathrm{min}$. EIMS: electron energy, $70 \mathrm{eV}$; ion source temperature was $230 \mathrm{0C}$.

Identification of constituents were done on the basis of Retention Index (RI, determined with reference to homologous series of n-alkanes C8-C28, under identical experimental condition), MS library search (NIST and WILEY), and by comparison with MS literature data [9]. The relative amounts of individual components were calculated based on GC peak area (FID response) without using correction factor. Retention indices (RI) were determined with reference to a homologous series of normal Alkanes.

\section{Extract Preparation for Antioxidant Analysis}

Take $1.0 \mathrm{ml}$ E. Oil of various code samples and mixed with in $4.0 \mathrm{ml}$ DMSO (Dimethyl sulfoxide). The prepared extract was used for the determination of antioxidant activity (i.e., DPPH assay \& ABTS assay) in among samples.

\section{Chemicals and Reagents}

1,1-Diphenyl-2-picrylhydrazyl (DPPH) radical, gallic acid, ascorbic acid, chlorogenic acid, caffeic acid, $\rho$-coumaric acid, 3-hydroxybenzoic acid, catechin and quercetin were procured from Sigma-Aldrich (Steinheim, Germany). Sodium carbonate, 2-(n-morpholino) ethanesulfonic acid (MES buffer), potassium persulphate, ferric chloride, sodium acetate, potassium acetate, aluminium chloride, glacial acetic acid and hydrochloric acid from Qualigens (Mumbai, India), and 2,2_-azinobis(3ethylbenzothiazoline-6-sulphonic acid) (ABTS), 2,4,6-tri-2pyridyl-1,3,5-triazin (TPTZ), methanol and ethanol from Merck Company (Darmstadt, Germany).

\section{Diphenyl-1-picrylhydrazyl (DPPH) Assay}

Free radical DPPH scavenging assay (Brand-Williams et al. [10]) was slightly modified for the present study. DPPH $(100 \mu \mathrm{M})$ was prepared in $80 \%(\mathrm{w} / \mathrm{v})$ ethanol and $2.7 \mathrm{ml}$ mixed with $0.9 \mathrm{ml}$ of sample extract and allowed to stand in the dark $(22 \pm 10 \mathrm{C}, 20$ $\mathrm{min})$. The reduction in the absorbance at $520 \mathrm{~nm}$ was recorded and results expressed in $\mathrm{mM}$ ascorbic acid equivalent per $100 \mathrm{~g}$ (mM AAE / $100 \mathrm{~g}$ ).

\section{Azinobis (3 benzylthiazole)-6- sulphonic acid (ABTS) Assay}

Total antioxidant activity was measured by improved ABTS (ethylbenzothiazoline 6- sulphonic acid) radical scavenging method [11]. In brief, ABTS $(7.0 \mu \mathrm{M})$ and potassium persulphate $(2.45 \mu \mathrm{M})$ were added in amber coloured bottle for the production of ABTS cation (ABTS $\left.{ }^{\circ}\right)$ and kept in the dark (16 h, $\left.22 \pm 1^{\circ} \mathrm{C}\right) \cdot \mathrm{ABTS}^{\circ}+$ solution was diluted with $80 \%(\mathrm{v} / \mathrm{v})$ ethanol till an absorbance of $0.700 \pm 0.05$ at $734 \mathrm{~nm}$ is obtained. For sample analysis, $3.90 \mathrm{ml}$ of diluted ABTS + solution was added to $0.10 \mathrm{ml}$ of methanolic extract and mixed thoroughly. The reaction mixture was allowed to stand $(22 \pm 1 \mathrm{oC}, 6 \mathrm{~min}$, dark $)$ and the absorbance was recorded at $734 \mathrm{~nm}$ with respect to blank. A standard curve of various concentrations of ascorbic acid is prepared in $80 \% \mathrm{v} / \mathrm{v}$ methanol for the equivalent quantification of antioxidant potential with respect to ascorbic acid. Results were expressed in $\mathrm{mM}$ ascorbic acid equivalent per $100 \mathrm{~g}(\mathrm{mM}$ AAE /100g).

\section{Results and Discussion}

\section{Essential Oil Composition}

Essential oil compositions of Leptodermis Lanceolata are presented in Table 1. The GC and GC-MS analysis of Leptodermis lanceolata resulted in the identification of 34 constituents, the oil yield was found to be $0.7 \%$ by weight. Both, the major as well as minor constituents were identified by their retention indices and comparison of their mass spectra. Total 34 constituents were identified constituting $72.24 \%$ of the total oil. The main compounds in major amounts were phytol 19.44\%, Linalool $12.12 \%$, n-Hexadecanoic acid 7.55\%, 4(E)-4-Hexenyl acetate $4.49 \%$, the compound in trace or in minor amount were 
$\gamma$-Cadinene $0.21 \%$, Neryl acetone $0.32 \%, 4,6$ - Dimethyl dodecane $0.32 \%$, The oxygenated diterpene $(36.68 \%)$, and oxygenated monoterpene $(20 \%)$, found in the oil as major components while

Table 1: Essential oil composition of Leptodermis Lanceolata.

\begin{tabular}{|c|c|c|c|c|c|c|}
\hline S.N. & Compound & Area \% & Mol. formula & Mol. Wt. & RI & $\begin{array}{l}\text { Mode of identify- } \\
\text { ication }\end{array}$ \\
\hline 1. & 2,4-Dimethyl-1-heptene & 0.52 & $\mathrm{C} 9 \mathrm{H}_{18}$ & 126 & 819 & $a, b$ \\
\hline 2. & Matsuika alcohol & 0.94 & $\mathrm{C}_{8} \mathrm{H} 1_{6} \mathrm{O}$ & 128 & 960 & $a, b$ \\
\hline 3. & (4E)-4-Hexenyl acetate & 4.49 & $\mathrm{C}_{8} \mathrm{H}_{14} \mathrm{O}_{2}$ & 142 & 986 & $\mathrm{a}, \mathrm{b}$ \\
\hline 4. & Benzofuran & 0.46 & $\mathrm{C}_{8} \mathrm{H}_{6} \mathrm{O}$ & 118 & 988 & $a, b$ \\
\hline 5. & Linalool & 12.12 & $\mathrm{C}_{10} \mathrm{H}_{18} \mathrm{O}$ & 154 & 1080 & $a, b$ \\
\hline 6. & 2-Methylcumarone & 0.69 & $\mathrm{C}_{9} \mathrm{H}_{8} \mathrm{O}$ & 132 & 1107 & $\mathrm{a}, \mathrm{b}$ \\
\hline 7. & Non-(2E)-enol & 0.37 & $\mathrm{C}_{9} \mathrm{H}_{18} \mathrm{O}$ & 142 & 1130 & $a, b$ \\
\hline 8. & 1-P-Menthen-8-ol & 3.27 & $\mathrm{C}_{10} \mathrm{H}_{18} \mathrm{O}$ & 154 & 1144 & $a, b$ \\
\hline 9. & Geraniol & 1.30 & $\mathrm{C}_{10} \mathrm{H}_{18} \mathrm{O}$ & 154 & 1255 & $a, b$ \\
\hline 10. & Dec-(2E)-ena & 0.33 & $\mathrm{C}_{10} \mathrm{H}_{18} \mathrm{O}$ & 154 & 1265 & $\mathrm{a}, \mathrm{b}$ \\
\hline 11. & 2-Methyl-1-decanol & 0.86 & $\mathrm{C}_{11} \mathrm{H}_{24} \mathrm{O}$ & 172 & 1270 & $\mathrm{a}, \mathrm{b}$ \\
\hline 12. & 4,6-Dimethyldodecane & 0.30 & $\mathrm{C}_{13} \mathrm{H}_{2} 8$ & 198 & 1285 & $a, b$ \\
\hline 13. & 1,1,6-Trimethyl-1,2-dihydronaphthalene & 1.53 & $\mathrm{C}_{13} \mathrm{H}_{16}$ & 172 & 1312 & $a, b$ \\
\hline 14. & (E)-, beta- Damascenone & 0.58 & $\mathrm{C}_{13} \mathrm{H}_{18} \mathrm{O}$ & 190 & 1360 & $a, b$ \\
\hline 15. & p-(isopropylidenecyclopropyl)- Toluene & 0.36 & $\mathrm{C}_{13} \mathrm{H}_{16}$ & 172 & 1368 & $a, b$ \\
\hline 16. & (E)-Caryophyllene & 1.46 & $\mathrm{C}_{15} \mathrm{H}_{24}$ & 204 & 1410 & $\mathrm{a}, \mathrm{b}$ \\
\hline 17. & Neryl Acetone & 0.32 & $\mathrm{C} 13 \mathrm{H}_{22} \mathrm{O}$ & 194 & 1422 & $a, b$ \\
\hline 18. & $\gamma$-Cadinene & 0.21 & $\mathrm{C}_{15} \mathrm{H} 24$ & 204 & 1507 & $a, b$ \\
\hline 19. & Cadina-1,4-diene & 1.89 & $\mathrm{C}_{15} \mathrm{H} 24$ & 204 & 1523 & $a, b$ \\
\hline 20. & $\alpha$-Cadinene & 1.50 & $\mathrm{C}_{15} \mathrm{H}_{24}$ & 204 & 1530 & $\mathrm{a}, \mathrm{b}$ \\
\hline 21. & (Z)-Nerolidol & 0.89 & $\mathrm{C}_{15} \mathrm{H}_{26} \mathrm{O}$ & 222 & 1531 & $\mathrm{a}, \mathrm{b}$ \\
\hline 22. & Fokienol & 2.32 & $\mathrm{C}_{15} \mathrm{H}_{24} \mathrm{O}$ & 220 & 1596 & $\mathrm{a}, \mathrm{b}$ \\
\hline 23. & Pogostol & 1.21 & $\mathrm{C}_{15} \mathrm{H}_{26} \mathrm{O}$ & 222 & 1640 & $\mathrm{a}, \mathrm{b}$ \\
\hline 24. & (Z)6,(Z)9-Pentadecadien-1-ol & 0.98 & $\mathrm{C}_{15} \mathrm{H}_{28} \mathrm{O}$ & 224 & 1771 & $\mathrm{a}, \mathrm{b}$ \\
\hline 25. & Hexadecanal & 0.68 & $\mathrm{C}_{16} \mathrm{H}_{32} \mathrm{O}$ & 240 & 1782 & $a, b$ \\
\hline 26. & Phytone & 0.67 & $\mathrm{C}_{18} \mathrm{H}_{36} \mathrm{O}$ & 268 & 1841 & $\mathrm{a}, \mathrm{b}$ \\
\hline 27. & n- Hexadecanoic acid & 7.55 & $\mathrm{C}_{16} \mathrm{H}_{32} \mathrm{O}_{2}$ & 256 & 1980 & $\mathrm{a}, \mathrm{b}$ \\
\hline 28. & 2-Hexyldodecanol & 0.88 & $\mathrm{C}_{18} \mathrm{H}_{38} \mathrm{O}$ & 270 & 1989 & $a, b$ \\
\hline 29. & ethyl-Palmitate & 0.82 & $\mathrm{C}_{18} \mathrm{H}_{36} \mathrm{O}_{2}$ & 284 & 1993 & $\mathrm{a}, \mathrm{b}$ \\
\hline 30. & Methyl octadeca-9,12-dienoate & 0.34 & $\mathrm{C}_{19} \mathrm{H}_{34} \mathrm{O}_{2}$ & 294 & 2093 & $a, b$ \\
\hline 31. & Methyl $\alpha$-linolenate & 1.40 & $\mathrm{C}_{19} \mathrm{H}_{32} \mathrm{O}_{2}$ & 292 & 2101 & $a, b$ \\
\hline 32. & Phytol & 19.44 & $\mathrm{C}_{20} \mathrm{H}_{40} \mathrm{O}$ & 296 & 2110 & $\mathrm{a}, \mathrm{b}$ \\
\hline 33. & Ethyl 9-octadecenoate & 0.41 & $\mathrm{C}_{20} \mathrm{H}_{38} \mathrm{O}_{2}$ & 310 & 2185 & $a, b$ \\
\hline \multirow[t]{2}{*}{34.} & (2E)-2-Nonadecanone o-methyloxime & 1.20 & $\mathrm{C}_{20} \mathrm{H}_{41} \mathrm{NO}$ & 311 & 2278 & $a, b$ \\
\hline & & 72.29 & & & & \\
\hline
\end{tabular}

sesquterpenes (5.72\%),were minor components. First time reported oil no previous report in this plant has been carried out (Table 1). 


\section{Antioxidant Activity}

Table 2: Antioxidant activity (DPPH \& ABTS assay) in Lepatodermis lenceolata.

\begin{tabular}{|l|c|c|}
\hline Name of plants & $\begin{array}{c}\text { DPPH activity } \\
\text { (mMAAE/100g) }\end{array}$ & $\begin{array}{c}\text { ABTS activity } \\
\text { (mMAAE/100g) }\end{array}$ \\
\hline Lepatodermis lenceolata & $4.78 \pm 0.01$ & $5.41 \pm 0.00$ \\
\hline
\end{tabular}

The essential oil showed good DPPH and ABTS radical scavenging activity. Antioxidant activity of plants Lepatodermis lenceolata analyzed (Table 2). The free radical scavenging activity (DPPH assay) was $4.78 \pm 0.01 \mathrm{mM} \mathrm{AAE} / 100 \mathrm{~g}$ recorded in Lepatodermis lenceolata aromatic oil. Total antioxidant activity (ABTS assay) was found $(5.41 \pm 0.00 \mathrm{mM} \mathrm{AAE} / 100 \mathrm{~g})$ in A. contorta aromatic oil (Table 2).

This activity is significant, especially since this essential oil are composed mainly of monoterpenes and sesquiterpenes hydrocarbons and oxygenated ones which have a moderate activity compared to phenolics and vitamin C. This result might be related to the antioxidant activity of our essential oil. All the essential oils had low amounts of phenolic compounds but showed good antioxidant activity. The diversified mono- and sesquiterpenoids present in the complex mixture of essential oils might be responsible for the good antioxidant activity because of synergetic effects of the constituents. This can be evidenced by a report which says that antioxidant capacity is affected by other bioactive compounds and could involve synergistic effects $[10,11]$.

\section{Conclusion}

The essential oil from Lepatodermis lanceolata showed a qualitative and quantitative make-up of constituents. The oils also showed good antioxidant activities. Clinically, this herb can be a good source of herbal medicine for the treatment of diseases indigenously. The study will also help to generate a database of species which can be exploited scientifically and judiciously in the future by local people and so that ecological balance is maintained. The results data obtained in the present study suggest that some essential oils possess strong medicinal activities, which can be utilized for treatment of certain diseases.

\section{Acknowledgement}

The authors are grateful to AIRF, Jawaharlal Nehru University, New Delhi for the Gas Chromatography coupled with Mass Spectrometry (GC-MS), and Gas Chromatography with flame ionization detection (GC-FID) analysis facilities \& Botanical Survey of India, for the identification of plant specimen. The authors are grateful to Dr. I. D. Bhatt Scientist-D, G.B.P.N.I.H.E.S.D., Kosi-Katarmal, Almora for provide antioxidant activity.

\section{Author Contributions}

The first author, Kavita Rawat persuade his Ph.D under the supervision of Prof Ganga Bisht carried out all the experiments work, Kundan Prasad the second author designed all the experiments and analyzed the data and prepared the manuscript. All authors read and approved the final manuscript.

\section{References}

1. World health organization regional office for the western pacific (1993) Research guidelines for evaluating the safety and efficacy of herbal medicines. Manila, World Health organization regional office for the western pacific.

2. Ishwari Datt Rai, Gajendra Singh, Gopal Singh Rawat (2015) Rediscovery, distribution and conservation status of Leptodermis riparia R. Parker (Rubiaceae) in Western Himalaya, India. Telopea 18: 79-83.

3. Dangwal LR, Antima Sharma, Rana CS (2010) Ethno-medicinal Plants of the Garhwal Himalaya Used to Cure Various Diseases: A Case Study. New York Science Journal 3(12):28-31.

4. Thatte U, Bagadey S, Dahanukar S (2000) Mole Cellular Bioche 46: 199214.

5. Sathisha AD, Lingaraju HB, Prasad SK (2011) Evaluation of Antioxidant Activity of Medicinal Plant Extracts Produced for Commercial Purpose. E-Journal of Chemistry 8(2): 882-886.

6. Ruban P, Gajalakshmi K (2012) In vitro antibacterial activity of Hibiscus rosa- sinensis flower extract against human pathogens. Asian pacific journal of tropical biomedicine 2(5): 399-403.

7. Calixto Joao B, Sirigiri Chandra Kala (2005) A Review on phytochemical Twenty-five years of researches on medicinal plants in Latin America A personal view, Journal of Ethno pharmacology 100: 131-134.

8. Lai LS, Chou ST (2001) Studies on the antioxidative activiaties of Hsiantsao (Mesona procumbens.Hemsl.) leaf gum. J Agric Food Chem 49: 963-968.

9. Adams RP (2001) Identification of Essential oil by Gas Chromatography Quadrupole Mass Spectrometry. Allured Publishing Corporation, Carol Stream. USA.

10. Cai Y, Luo Q, Sun M, Corke H (2004) Antioxidant activity and phenolic compounds of 112 traditional Chinese medicinal plants associated with anticancer. Life Sciences 74: 2157-2184.

11. Sanchez MC, Larrauri JA, Saura CF (1999) Free radical scavenging capacity and inhibition of lipid oxidation of wines, grape juices and related polyphenolic constituents. Food Res Int 32: 407-412. 
(C) Commons Attribution 4.0 License

BY DOI: 10.19080/JPCR.2017.04.555630

\section{Your next submission with Juniper Publishers will reach you the below assets}

- Quality Editorial service

- Swift Peer Review

- Reprints availability

- E-prints Service

- Manuscript Podcast for convenient understanding

- Global attainment for your research

- Manuscript accessibility in different formats ( Pdf, E-pub, Full Text, Audio)

- Unceasing customer service

Track the below URL for one-step submission https://juniperpublishers.com/online-submission.php 